\title{
L-Type Calcium Channels Govern Calcium Signaling in Migrating Newborn Neurons in the Postnatal Olfactory Bulb
}

\author{
Daniel P. Darcy and Jeffry S. Isaacson \\ Department of Neuroscience, University of California, San Diego School of Medicine, La Jolla, California 92093
}

\begin{abstract}
Newborn inhibitory neurons migrate into existing neural circuitry in the olfactory bulb throughout the lifetime of adult mammals. While many factors contribute to the maturation of neural circuits, intracellular calcium is believed to play an important role in regulating cell migration and the development of neural systems. However, the factors underlying calcium signaling within newborn neurons in the postnatal olfactory bulb are not well understood. Here, we show that migrating, immature neurons in the olfactory bulb subependymal layer (SEL) undergo spontaneous and depolarization-evoked intracellular calcium transients mediated by high-voltage-activated L-type calcium channels. In contrast to migrating immature neurons in other brain regions, modulation of calcium transients in SEL cells does not alter their rate of migration.
\end{abstract}

Key words: olfactory bulb; calcium channels; migration; interneurons; development; subventricular zone

\section{Introduction}

Adult neurogenesis has been demonstrated in many animal species (Gross, 2000) including humans (Eriksson et al., 1998; Curtis et al., 2007). Adult-born neurons in both the hippocampal dentate gyrus and olfactory bulb have been shown to develop the morphology, membrane properties, and synaptic connectivity characteristic of mature neurons (van Praag et al., 2002; Belluzzi et al., 2003). Sensory experience and behavior regulate the extent of adult neurogenesis that occurs. For example, voluntary exercise and enriched environment increase cell numbers in the dentate gyrus (Kempermann et al., 1997; Brown et al., 2003a; van Praag et al., 2005), while the survival (Petreanu and AlvarezBuylla, 2002; Alonso et al., 2006) and response (Magavi et al., 2005) of new neurons in the olfactory bulb is modulated by olfactory experience.

In the olfactory system, neural precursor cells (NPCs) are born in the subventricular zone (SVZ) (Lois and Alvarez-Buylla, 1994) and migrate along the rostral migratory stream (RMS) to the olfactory bulb (Luskin, 1998). NPCs from the RMS are densely concentrated in the inner core of the olfactory bulb within a region termed the subependymal layer (SEL). NPCs ultimately exit the SEL, migrate radially, and mature into local GABAergic interneurons of the bulb (Baker et al., 2001; Belluzzi et al., 2003; Carleton et al., 2003). Throughout adult life, NPCs in the SEL are a source for new granule and periglomerular cells that provide inhibition onto principal mitral and tufted cells, thus shaping sensory processing in the bulb.

\footnotetext{
Received Nov. 5, 2008; revised Jan. 12, 2009; accepted Jan. 20, 2009.

This work was supported by National Institute on Deafness and Other Communication Disorders Grant R01 DC04682 and the Klingenstein Foundation. We thank Massimo Scanziani for helpful comments.

Correspondence should be addressed to Jeffry S. Isaacson, Department of Neuroscience, Center for Molecular Genetics, Room 213, University of California, San Diego, 9500 Gilman Drive, La Jolla, CA 92093-0634. E-mail: jisaacson@ucsd.edu.

DOI:10.1523/JNEUROSCI.5333-08.2009

Copyright $\odot 2009$ Society for Neuroscience $\quad$ 0270-6474/09/292510-09\$15.00/0
}

The intracellular events that control neuronal migration in the postnatal brain are of great interest (Komuro and Rakic, 1998; Gage, 2002; Ming and Song, 2005). Changes in intracellular $\mathrm{Ca}^{2+}$ have been suggested to play an important role in neuronal migration during embryonic and early postnatal development. For example, an increase in the frequency of intracellular $\mathrm{Ca}^{2+}$ transients mediated by $\mathrm{N}$-type $\mathrm{Ca}^{2+}$ channels enhances migration of granule cells in the developing cerebellum (Komuro and Rakic, 1992, 1996, 1998). Furthermore, intracellular $\mathrm{Ca}^{2+}$ appears to play an important role in the motility of growth cones and neurite extension in developing neurons (Gomez and Spitzer, 1999; Lautermilch and Spitzer, 2000; Zheng, 2000; Gomez et al., 2001; Wen et al., 2004).

Previous electrophysiological studies have explored the intrinsic membrane properties of neuroblasts in the SVZ and RMS. Neuroblasts in these migratory zones express voltage-dependent, delayed-rectifier $\mathrm{K}^{+}$currents and small voltage-gated $\mathrm{Na}^{+}$currents that are insufficient to evoke fast action potentials (Belluzzi et al., 2003; Wang et al., 2003b). Removal of extracellular $\mathrm{Ca}^{2+}$ reduced a fraction of $\mathrm{K}^{+}$current, suggesting the presence of $\mathrm{Ca}^{2+}$-dependent $\mathrm{K}^{+}$channels in olfactory neural progenitors (Wang et al., 2003b). However, it is unclear if migrating olfactory NPCs express voltage-gated $\mathrm{Ca}^{2+}$ channels.

In this study, we examine the membrane properties and intracellular $\mathrm{Ca}^{2+}$ dynamics of NPCs migrating within the SEL in acute slices of the postnatal olfactory bulb. We show that NPCs generate spontaneous and depolarization-evoked $\mathrm{Ca}^{2+}$ transients mediated by dihydropyridine-sensitive L-type $\mathrm{Ca}^{2+}$ channels. Furthermore, voltage-clamp recordings from SEL cells reveal high-voltage-activated (HVA) L-type $\mathrm{Ca}^{2+}$ currents. We use two-photon laser-scanning microscopy (2PLSM) to track migration of SEL cells in acute olfactory bulb slices and find that neither blocking nor enhancing $\mathrm{Ca}^{2}$ influx via L-type channels alters the rate of NPC migration. These results suggest that $\mathrm{Ca}^{2+}$ transients do not directly govern migration rate in olfactory bulb NPCs. 

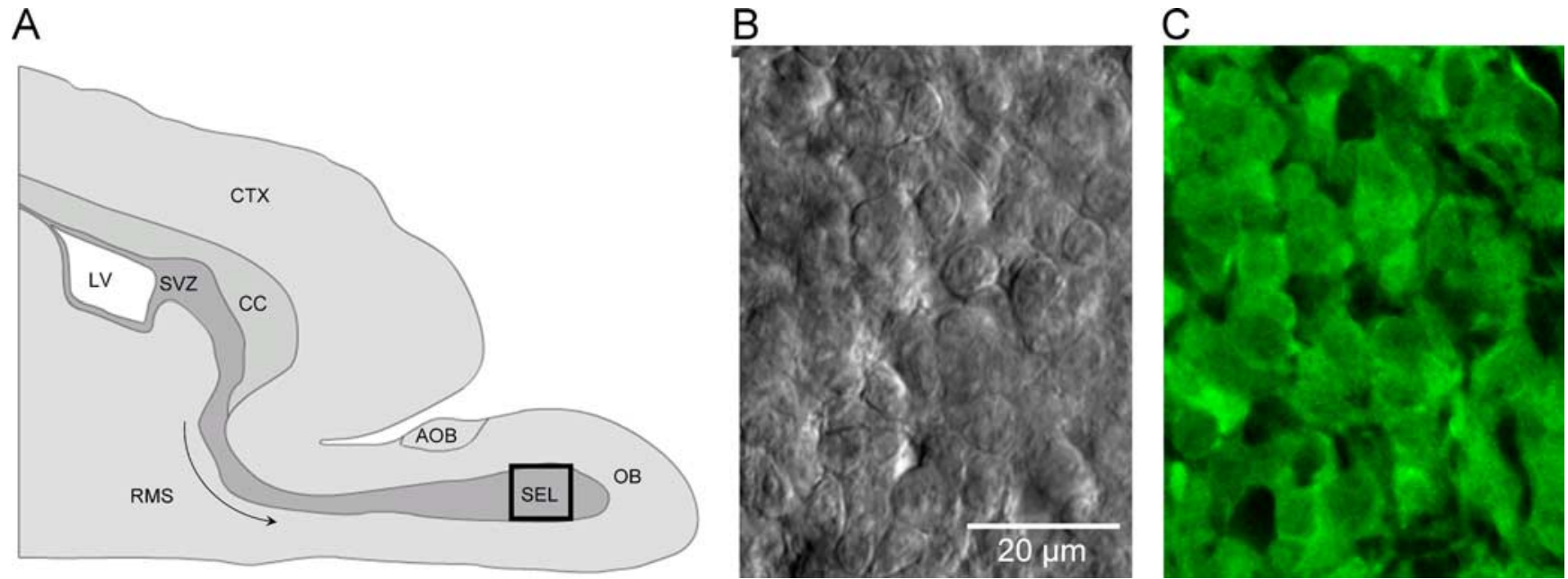

Figure 1. Migration route and molecular identity of NPCs in the postnatal olfactory bulb. $A$, Tangential migration of NPCs from their site of proliferation in the SVZ, through the RMS and into the SEL of the olfactory bulb (OB). Box shows area imaged for migration experiments. AOB, Accessory olfactory bulb; CC, corpus callosum; CTX, cortex; LV, lateral ventricle. B, C, DIC (B) and GFP ( $C$ ) fluorescence images of a field of NPCs from a GFP-doublecortin transgenic mouse.

\section{Materials and Methods}

Slice preparation and electrophysiology. Olfactory bulb slices $(350 \mu \mathrm{m})$ were prepared from 1- to 3-month-old FVB/N-Swiss Webster mice [for examination of doublecortin (DCX) expression] or 16- to 30-d-old Sprague Dawley rats (all other studies) in accordance with institutional and national guidelines using standard procedures. Slices were prepared and maintained in artificial CSF (aCSF) containing (in mM) $83 \mathrm{NaCl}, 2.5$ $\mathrm{KCl}, 3.3 \mathrm{MgSO}_{4}, 1 \mathrm{NaH}_{2} \mathrm{PO}_{4}, 26.2 \mathrm{NaHCO}_{3}, 22$ glucose, 72 sucrose and $0.5 \mathrm{CaCl}_{2}$ equilibrated with $95 \% \mathrm{O}_{2} / 5 \% \mathrm{CO}_{2}$ at $34^{\circ} \mathrm{C}$ for $30 \mathrm{~min}$ and at room temperature thereafter. In the recording chamber, slices were viewed using infrared-differential interference contrast (DIC) optics (BX-51W1, Olympus) and superfused with aCSF containing (in mM) 119 $\mathrm{NaCl}, 2.5 \mathrm{KCl}, 1.3 \mathrm{MgSO}_{4}, 1 \mathrm{NaH}_{2} \mathrm{PO}_{4}, 26.2 \mathrm{NaHCO}_{3}, 22$ glucose and 2.5 $\mathrm{CaCl}_{2}$ equilibrated with $95 \% \mathrm{O}_{2} / 5 \% \mathrm{CO}_{2}$.

Whole-cell electrodes $(\sim 6-7 \mathrm{M} \Omega)$ for voltage- and current-clamp recordings were filled with a solution containing (in $\mathrm{mm}$ ) 115.5 $\mathrm{KCH}_{3} \mathrm{SO}_{4}, 17.5 \mathrm{KCl}, 10$ HEPES, 10 phosphocreatine, $3 \mathrm{Mg}$-ATP, 0.5 $\mathrm{Na}$-GTP, 0.5 EGTA ( $\mathrm{pH} \sim 7.3,300 \mathrm{mOsm}$ ). For recording $\mathrm{Ca}^{2+}$ spikes in current-clamp and isolating $\mathrm{Ca}^{2+}$ currents, the internal solution was (in mM) 130 D-gluconic acid, $130 \mathrm{CsOH}, 5 \mathrm{NaCl}, 3 \mathrm{Mg}$-ATP, $0.2 \mathrm{Na}$-GTP, 12 phosphocreatine, 10 HEPES, 5-10 EGTA ( $\mathrm{pH} \sim 7.3,300 \mathrm{mOsm}$ ), and the aCSF included $100 \mu \mathrm{M}$ picrotoxin (PTX), $1 \mu \mathrm{M}$ TTX, $1 \mathrm{~mm}$ 4 -aminopyridine and $4 \mathrm{~mm}$ tetraethylammonium (TEA). The holding potential was $-80 \mathrm{mV}$ unless otherwise noted.

Responses were recorded with an Axopatch 200B amplifier (Axon Instruments), filtered at $2-5 \mathrm{kHz}$ and digitized at $10-20 \mathrm{kHz}$ (ITC-18; Instrutech). Data acquisition and analysis were performed with Axograph 4.9 (Axon) or Axograph X (AxoGraph Scientific) and IGOR Pro 5/6 (Wavemetrics). Experiments were corrected for a measured junction potential $(\sim 10 \mathrm{mV}) . \mathrm{Ca}^{2+}$ currents were determined using leak subtraction $(\mathrm{P} / 4)$ and isolated by subtracting the $\mathrm{Cd}^{2+}$ insensitive current component from voltage-clamp recordings. Current recordings were obtained at room temperature.

Imaging. For imaging of spontaneous and evoked $\mathrm{Ca}^{2+}$ transients, olfactory bulb slices were bulk loaded with Oregon Green-1 BAPTA AM (30 $\mu \mathrm{M} ; 1.7 \%$ DMSO and 0.05\% Pluronic F-127 in aCSF; Invitrogen) in aCSF at $34^{\circ} \mathrm{C}$ for $40-60 \mathrm{~min}$, and experiments were performed at room temperature. Image acquisition (494 $\mathrm{nm}$ excitation, $2 \times 2$ binning, 2-4 $\mathrm{Hz}$ capture) and analysis were performed with a cooled-CCD camera system (T.I.L.L. Photonics). Regions of interest (ROIs) were small circles centered on the soma of NPCs. Events were detected using a derivative thresholding method (Axograph X).

To study NPC migration, slices were focally loaded in the SEL via 2 min of light pressure ejection from a glass pipette with CellTracker Green 5 -chloromethylfluorescein diacetate (CMFDA) $(30 \mu \mathrm{M}, 1.7 \%$ DMSO in
aCSF) at $34^{\circ} \mathrm{C}$. Slices were stabilized in the imaging chamber for $1 \mathrm{~h}$ before data acquisition. 2PLSM of NPC migration was performed using an ultrafast pulsing Ti:sapphire laser (MaiTai, Newport) coupled via standard optics (SD Instruments) to a modified laser-scanning microscope (Fluoview 300, Olympus) equipped with photomultiplier tube detectors (R3896, Hamamatsu) in a non-descanned configuration. Threedimensional time lapses were processed to obtain two-dimensional maximum-intensity projections of NPC migration, and "celltracks" were made by manually tracking all somata that remained visible and displaced at least $20 \mu \mathrm{m}$ during the course of an experiment. Each celltrack was normalized to its own average velocity during the control period. All migration experiments were performed at $34^{\circ} \mathrm{C}$ in the presence of (in $\mu \mathrm{M}) 1$ TTX, 20 bicuculline methobromide, 100 PTX, 50 APV, and 40 MK-801 to block transmitter release in the slice and $\mathrm{GABA}_{\mathrm{A}}$ and NMDA receptors on NPCs and other cell types.

Analysis. Representative traces are the average of five or more consecutive episodes, except where noted. Data are presented as mean \pm SEM. Student's $t$ test was used to determine statistical significance.

\section{Results}

NPCs migrate tangentially from the lateral ventricle to the SEL of the olfactory bulb (Fig. $1 A$ ) and then migrate radially to the granule cell layer and glomerular layer of the bulb. Previous studies suggest that the majority of cells in the SEL of the olfactory bulb are migrating NPCs (Luskin, 1998). To confirm this, we first examined the expression of DCX, a microtubule-associated protein found selectively in migrating newborn migrating neurons (Gleeson et al., 1999; Nacher et al., 2001; Brown et al., 2003b). Acute brain slices from mice expressing green fluorescent protein (GFP) driven by the DCX promoter confirmed that virtually all cells in the SEL express this marker of migrating neurons (Fig. $1 B, C)$.

We next made whole-cell recordings to characterize the intrinsic electrical membrane properties of NPCs. Consistent with previous findings (Belluzzi et al., 2003; Wang et al., 2003b), these cells had a high input resistance $\left(R_{\mathrm{in}}=3.6 \pm 0.5 \mathrm{G} \Omega ; n=6\right)$ and a resting membrane potential of $-26.4 \pm 1.6 \mathrm{mV}$ ( $n=30$ cells). This depolarized resting potential is likely to be distorted by the very high input resistance of the cells relative to the seal resistance. Indeed, the resting membrane potential of NPCs estimated from cell-attached recordings of $\mathrm{K}^{+}$channels is approximately $-60 \mathrm{mV}$ (Wang et al., 2003b). When NPCs were held between -60 and $-80 \mathrm{mV}$ in current clamp, depolarizing current steps to 
$A_{1}$
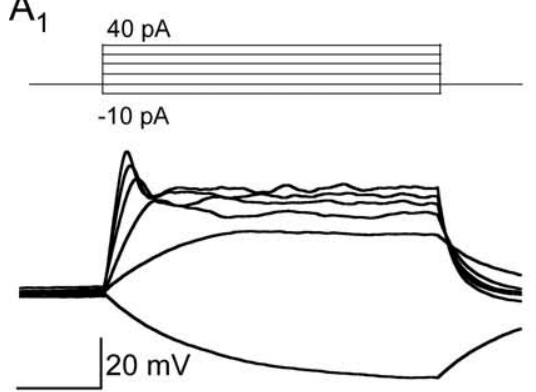

$100 \mathrm{~ms}$
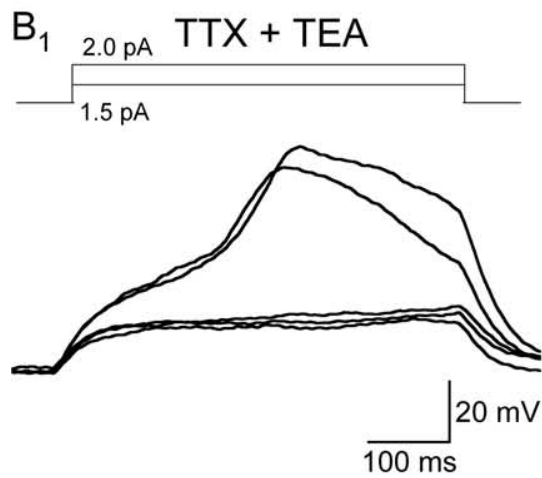

$\mathrm{C}_{1}$
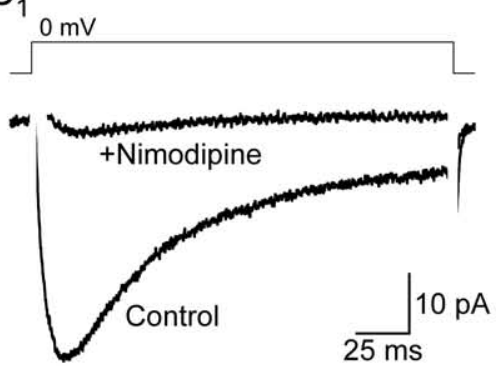

$\mathrm{A}_{2}$
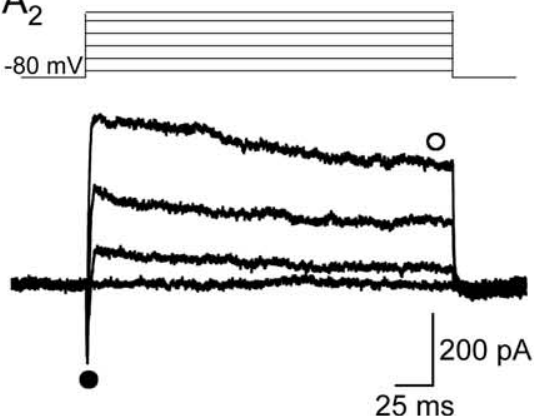

$\mathrm{B}_{2}$ $-80 \mathrm{mV}$

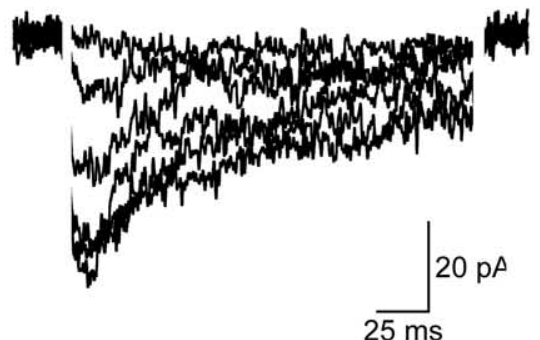

$\mathrm{C}_{2}$

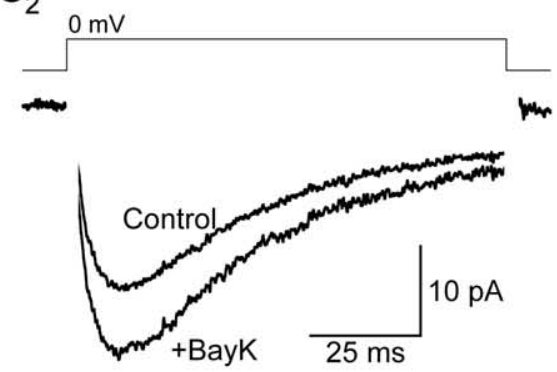

$\mathrm{A}_{3}$

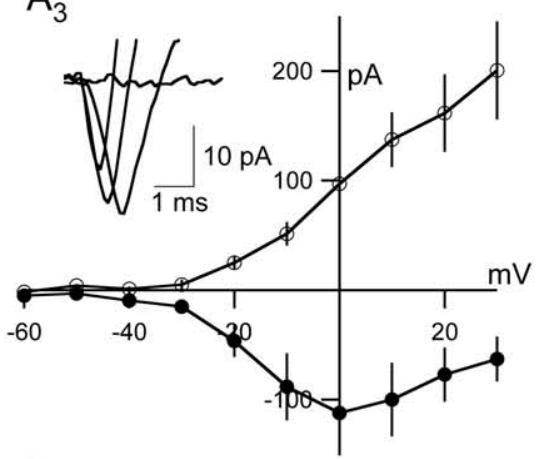

$\mathrm{B}_{3}$

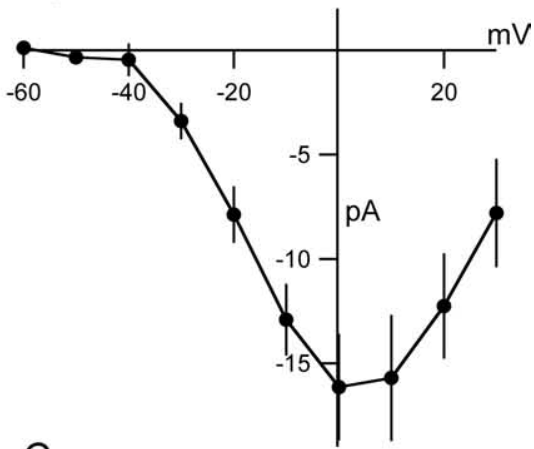

$\mathrm{C}_{3}$

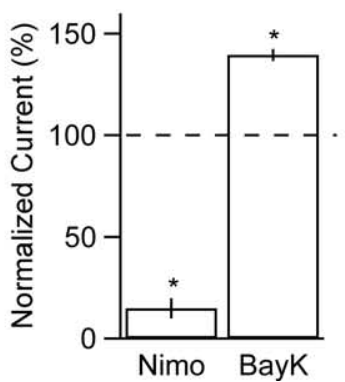

Figure 2. Membrane properties and L-type $\mathrm{Ca}^{2+}$ currents in NPCs of the olfactory bulb SEL. $\boldsymbol{A}_{1}$, Membrane potential of an NPC (bottom) in response to step injections of current (top). $\boldsymbol{A}_{2}$, Voltage-clamp recording (top; $V_{\mathrm{m}}=-80 \mathrm{mV}$ ) of an NPC with mixed Na ${ }^{+}$(filled circle) and $\mathrm{K}^{+}$current (open circle). $A_{3}$, Summary IV plot of early (filled circles) and late currents (open circles, $n=$ 8 cells). Inset, early currents shown expanded from $\boldsymbol{A}_{2} \cdot \boldsymbol{B}_{1}$, Example traces of a regenerative spike elicited by small current injections in an NPC in the presence of TTX and TEA. $\boldsymbol{B}_{2}$, Example traces of $\mathrm{Ca}^{2+}$ currents elicited by voltage-steps and $\boldsymbol{B}_{3}$, summary IV plot of HVA Ca ${ }^{2+}$ channel activity $\left(n=7\right.$ cells). $\boldsymbol{C}$, Representative experiments showing NPC $\mathrm{Ca}^{2+}$ current blocked by nimodipine $\left(\boldsymbol{C}_{1}\right.$, $20 \mu \mathrm{M})$ and enhanced by BayK $8644\left(\boldsymbol{C}_{2}, 10 \mu \mathrm{M}\right) . \boldsymbol{C}_{3}$, Summary of the effects of nimodipine $(n=6)$ and BayK8644 $(n=6)$ on NPC $\mathrm{Ca}^{2+}$ current. Asterisks indicate significantly different from control.

$0 \mathrm{mV}$ failed to generate fast action potentials in response to depolarizing current steps (Fig. $\left.2 A_{1}\right)(n=8)$. In voltage-clamp recordings, membrane depolarization evoked small transient inward currents (Fig. $2 A_{2,3}$, filled circles and inset) and sustained outward currents (Fig. $2 A_{2,3}$, open circles). The rapid inward currents were abolished by TTX ( $1 \mu \mathrm{M}$; data not shown), indicating that they are mediated by voltage-gated sodium channels. The sustained outward currents have previously been shown to be generated by voltage-gated $\mathrm{K}^{+}$channels (Wang et al., 2003b). Presumably the small amplitude of $\mathrm{Na}^{+}$current relative to $\mathrm{K}^{+}$ current in NPCs prevents the generation of $\mathrm{Na}^{+}$channelmediated action potentials.

In the presence of TTX and the potassium channel blockers TEA and $\mathrm{Cs}^{+}$, small depolarizing current injections evoked slow regenerative spikes in NPCs (Fig. $\left.2 B_{1}\right)(n=3)$. These events were blocked after application of the broad-spectrum $\mathrm{Ca}^{2+}$ channel antagonist $\mathrm{Cd}^{2+}(200 \mu \mathrm{M}$; data not shown). Voltage-clamp recordings in the presence of TTX and TEA revealed $\mathrm{Cd}^{2+}$ sensitive currents consistent with HVA Ca ${ }^{2+}$ channels (Fig. $\left.2 B_{2,3}\right)(n=7)$. $\mathrm{Ca}^{2+}$ currents evoked by voltage steps to $0 \mathrm{mV}$ were blocked by the dihydropyridine antagonist nimodipine (Fig. $\left.2 C_{1,3}\right)(20 \mu \mathrm{M}$, $14.8 \pm 5 \%$ of control, $n=6)$ and enhanced by the agonist BayK 8644 (Fig. $\left.2 C_{2,3}\right)(10 \mu \mathrm{M}, 139.5 \pm 3 \%$ of control, $n=6)$. Thus, NPCs express voltage-gated L-type $\mathrm{Ca}^{2+}$ channels that could provide a mechanism for $\mathrm{Ca}^{2+}$ influx.

To further explore $\mathrm{Ca}^{2+}$ signaling in NPCs, we bulk loaded olfactory bulb slices with the $\mathrm{Ca}^{2+}$ indicator Oregon Green BAPTA-1 A.M. (OG1-AM) and collected fluorescent time lapse data of fields of SEL cells. We observed spontaneous transient elevations of $\mathrm{Ca}^{2+}$ in $25-50 \%$ of all dye-loaded NPCs over a 4 to 8 min imaging period (Fig. $3 A)\left(n=9\right.$ slices). $\mathrm{Ca}^{2+}$ transients occurred as unitary events or bursts of events with similar amplitudes (Fig. $3 \mathrm{~A}_{2}$ ). Spontaneous $\mathrm{Ca}^{2+}$ transients had an average $10-90 \%$ rise time of $914 \pm 45 \mathrm{~ms}$ and half decay time of $4.25 \pm$ $0.17 \mathrm{~s}$ (Fig. $\left.3 A_{3}\right)(n=133$ transients from 90 cells in 4 slices $)$. The slow decay time may reflect slow $\mathrm{Ca}^{2+}$ clearance from SEL cells. It has previously been shown that coordinated fluctuations in intracellular $\mathrm{Ca}^{2+}$ occur in precursor neurons of the ventricular zone via gap junction coupling (Owens and Kriegstein, 1998). To test this possibility in NPCs, we measured the frequency with 


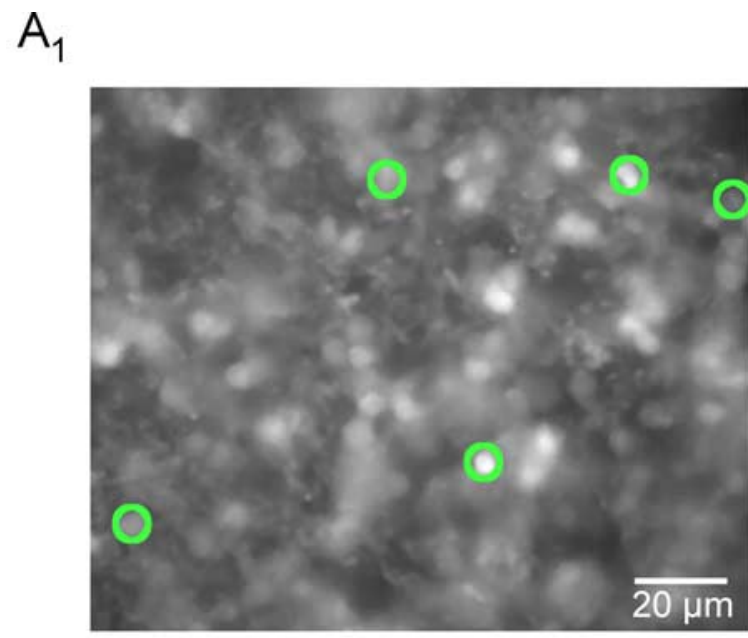

$\mathrm{A}_{2}$
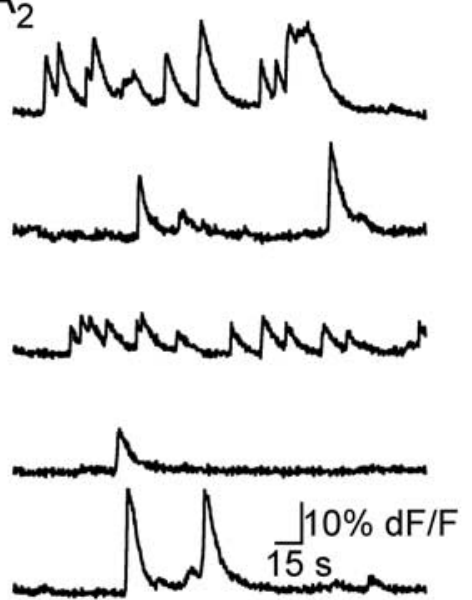

$\mathrm{A}_{3}$
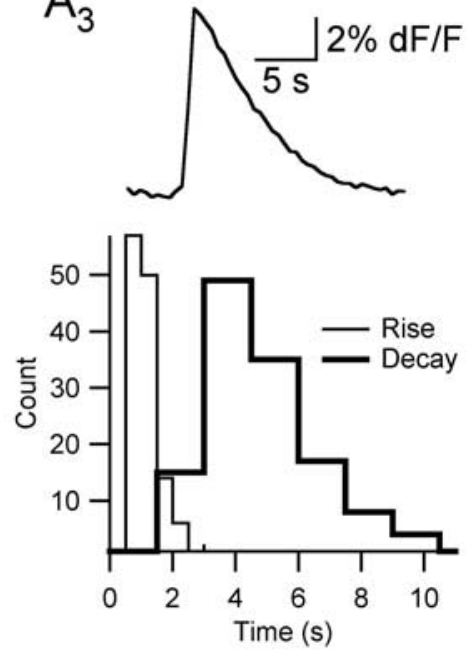
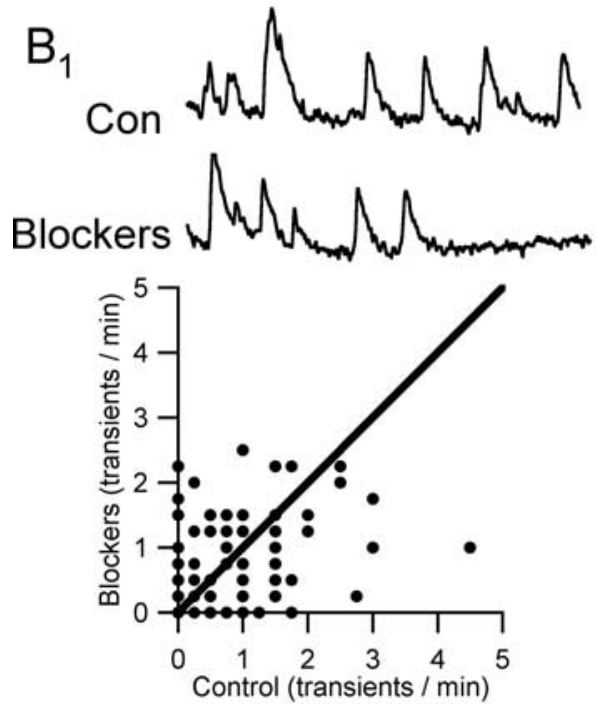

$\mathrm{B}_{2}$
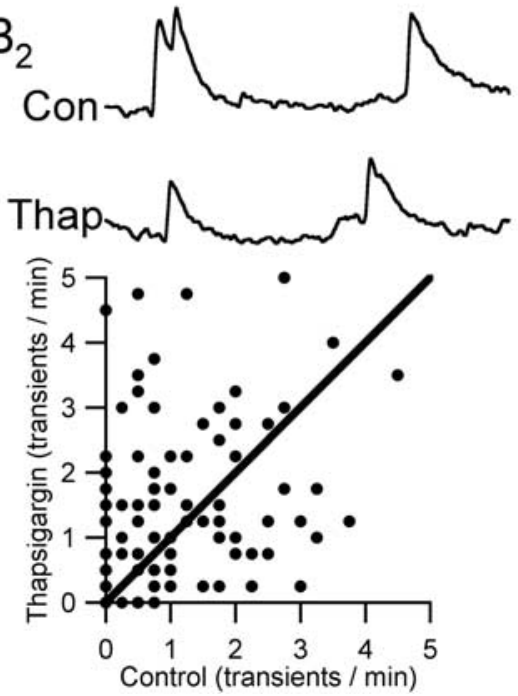

$\mathrm{B}_{3}$ 3 Cons $5 \% \mathrm{dF} / \mathrm{F}$
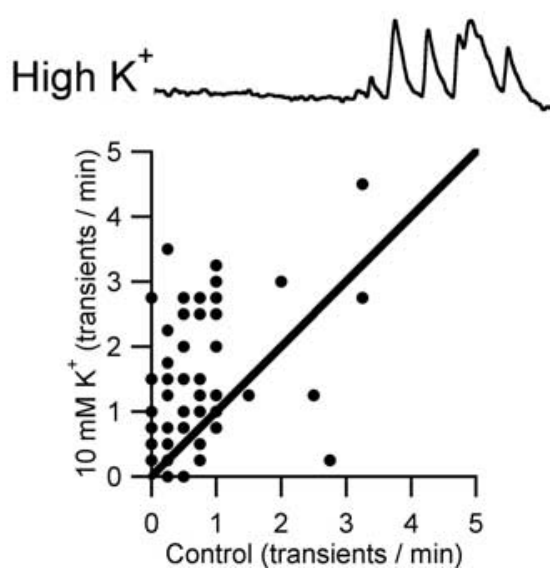

Figure 3. Spontaneous $\mathrm{Ca}^{2+}$ transients in NPCs in the olfactory bulb. $A_{1}$, Fluorescence image of NPCs in an acute rat bulb slice loaded with 0G1-AM. Circular ROIs are centered on five individual cells. $A_{2}$, Delta $F / F$ traces of average changes in fluorescence intensity within each ROl in $A_{1} . A_{3}$, Top, Trace of aligned and averaged spontaneous $\mathrm{Ca}^{2+}$ transients $(n=133)$. Bottom, Histograms of unitary transient rise (thin trace) and decay (thick trace) times. $\boldsymbol{B}_{1}, \mathrm{Ca}^{2+}$ transient frequency is unaffected by coapplication of TTX (1 $\left.\mu \mathrm{M}\right), \mathrm{NBQX}(20 \mu \mathrm{M}), \mathrm{APV}(50 \mu \mathrm{M})$ and gabazine (25 $\left.\mu \mathrm{M}\right)$. Top, Traces from a representative cell before and after application of blockers. Bottom, Summary results of transient frequency under control conditions and after drug application for individual cells $(n=$ 30 cells, 3 slices). $\boldsymbol{B}_{2}$, Thapsigargin does not alter the frequency of $\mathrm{Ca}^{2+}$ transients. Example traces (top) and frequency of transients (bottom) during control conditions and after application of thapsigargin (5-10 $\mu \mathrm{m}, n=46$ cells, 5 slices). $\boldsymbol{B}_{\mathbf{3}}$, Membrane depolarization increases the frequency of $\mathrm{Ca}^{2+}$ transients. Example traces (top) and transient frequency (bottom) during control conditions and after application of aCSF containing $10 \mathrm{~mm} \mathrm{~K}^{+}(n=57$ cells, 3 slices).

which $\mathrm{Ca}^{2+}$-transient elevations occurred in adjacent pairs of cells. We counted $\mathrm{Ca}^{2+}$ events as simultaneous if an elevation onset occurred in two adjacent cells within a $10 \mathrm{~s}$ time window. This frequency was not greater than when individually measuring coincident activity between each of the cells from an adjacent pair and a random distant cell in the image field $(6.8 \pm 0.7 \%$ coincidence for adjacent cells, $7.1 \pm 0.5 \%$ coincidence for randomly paired cells; $n=$ 43 cells, 3 slices). Thus, we did not find evidence for coordinated $\mathrm{Ca}^{2+}$ signaling via gap junctions in olfactory bulb NPCs.

What is the underlying source of spontaneous $\mathrm{Ca}^{2+}$ transients in olfactory bulb NPCs? To test whether endogenous neurotransmitter receptors may govern spontaneous $\mathrm{Ca}^{2+}$ elevations in NPCs, we imaged $\mathrm{Ca}^{2+}$ activity in these cells before and after application of a blocker mixture containing (in $\mu \mathrm{M}$ ) 1 TTX, 50 APV, 20 NBQX and 25 SR-95531 (Gabazine) to block $\mathrm{Na}^{+}$channels, NMDA receptors (NMDARs), AMPA receptors (AMPARs), and $\mathrm{GABA}_{\mathrm{A}}$ receptors $\left(\mathrm{GABA}_{\mathrm{A}} \mathrm{Rs}\right)$, respectively. Transient frequency was not affected by the blockers (Fig. $3 B_{1}$ ) (transients per minute in control: $0.77 \pm 0.09$; blockers: $0.72 \pm 0.07 ; n=95$ cells, 3 slices), indicating that spontaneous transients are not due to activation of ionotropic neurotransmitter receptors. To test for a contribution of intracellular $\mathrm{Ca}^{2+}$ stores, we did similar experiments in the same blocker mixture quantifying transient frequency before and after the addition of thapsigargin (5-10 $\mu \mathrm{M})$. Transients persisted in the presence of thapsigargin (Fig. $3 B_{2}$ ) (transients per minute in control: $1.39 \pm 0.13$; thapsigargin: $1.61 \pm 0.13 ; n=91$ cells, 5 slices), discounting a role for thapsigargin-sensitive $\mathrm{Ca}^{2+}$ stores in the generation of $\mathrm{Ca}^{2+}$ transients. We next tested whether membrane depolarization could increase the frequency of transients. In the presence of TTX and neurotransmitter receptor blockers, elevation of extracellular $\mathrm{K}^{+}$from 2.5 to $10 \mathrm{~mm}$ strongly increased transient frequency (Fig. $3 B_{3}$ ) (transients per minute in control: $0.72 \pm 0.11$; high $\mathrm{K}^{+}: 1.36 \pm 0.14 ; n=57$ cells, 3 slices). Together, these results suggest that voltage-dependent $\mathrm{Ca}^{2+}$ channels underlie spontaneous $\mathrm{Ca}^{2+}$ transients in olfactory bulb NPCs. 


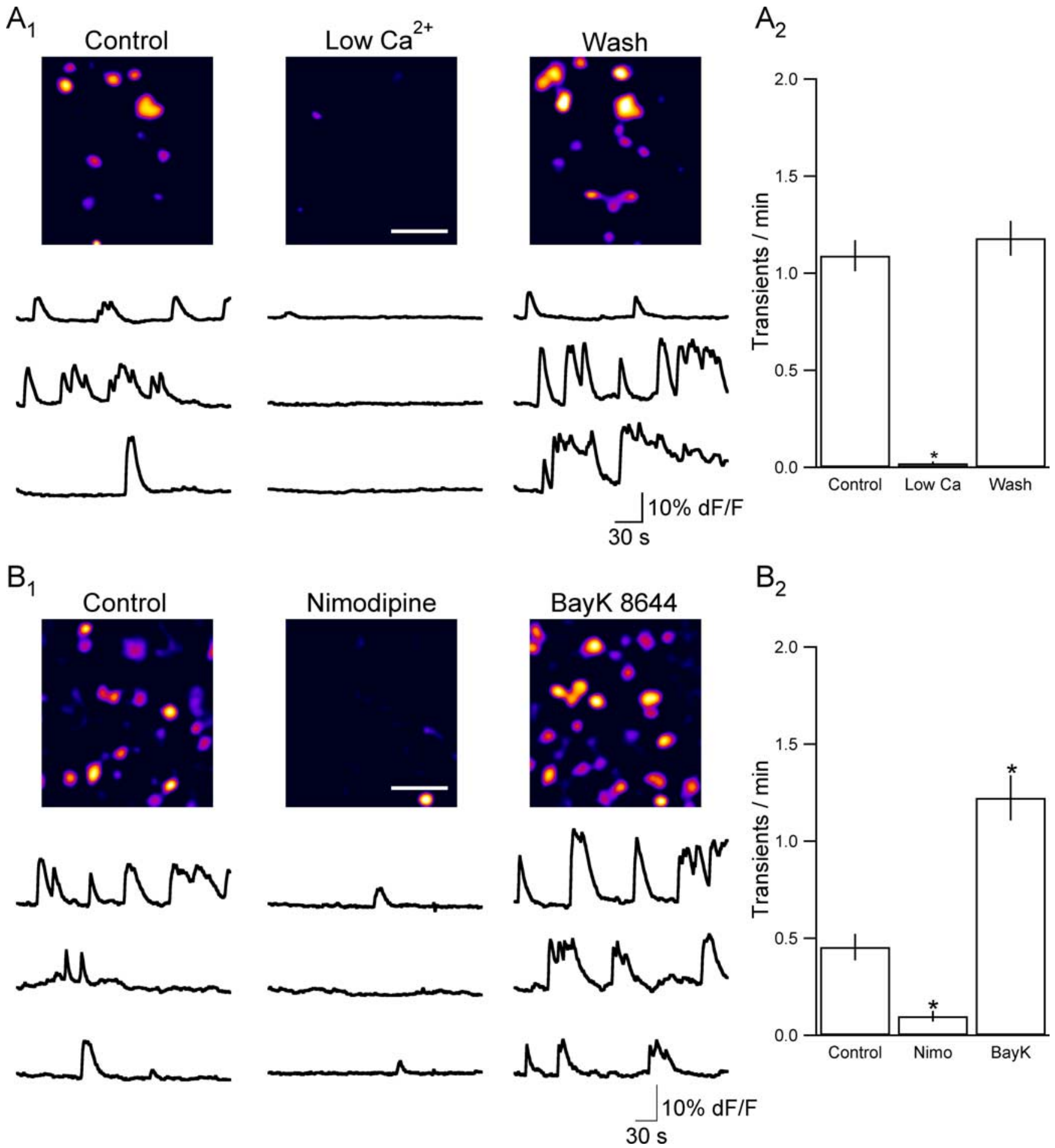

Figure 4. Spontaneous $\mathrm{Ca}^{2+}$ transients require $\mathrm{Ca}^{2+}$ influx and are mediated by L-type $\mathrm{Ca}^{2+}$ channels. $\boldsymbol{A}_{1}$, Top, Example widefield delta $F / F$ time projections demonstrating NPC transient activity under control conditions, in the presence of nominally $\mathrm{Ca}^{2+}$-free, and after wash. Scale bar, $20 \mu \mathrm{m}$. Bottom, Traces from ROls centered over the 3 cells during each condition. $\boldsymbol{A}_{2}$, Summary of transient frequency $\left(n=116\right.$ cells, 4 slices). $\boldsymbol{B}_{1}$, Top, Example widefield delta $F / F$ time projections of transients under control conditions, after application of nimodipine, and subsequent wash-in of BayK 8644. Scale bar, $20 \mu \mathrm{m}$. Bottom, Traces from ROls centered over 3 cells during each condition. $\boldsymbol{B}_{2}$, Average change in $\mathrm{Ca}^{2+}$ transient frequency in response to nimodipine and BayK 8644 (control: $0.45 \pm 0.07$, nimodipine: $0.10 \pm 0.03$, Bayk: $1.22 \pm 0.12 ; n=60$ cells, 4 slices).

Spontaneous transients required influx of extracellular $\mathrm{Ca}^{2+}$ since they were largely abolished in the presence of modified aCSF containing $1 \mathrm{~mm}$ EGTA, $0.5 \mathrm{~mm} \mathrm{Ca}^{2+}$ and $3.3 \mathrm{~mm} \mathrm{Mg}^{2+}$ (Fig. 4 A) $\left[n=116\right.$ cells, 4 slices; predicted free extracellular $\mathrm{Ca}^{2+}$ concentration of $\sim 60 \mathrm{~nm}$ (Patton et al., 2004)]. To confirm a role for voltage-gated $\mathrm{Ca}^{2+}$ channels, we tested the effect of selective modulators of L-type $\mathrm{Ca}^{2+}$ channels on spontaneous $\mathrm{Ca}^{2+}$ transients in NPCs (Fig. $4 B)$ ( $n=60$ cells, 4 slices). In the presence of TTX and the neurotransmitter receptor blocker mixture, transients were largely abolished by the L-type $\mathrm{Ca}^{2+}$ channel antagonist nimodipine $(30 \mu \mathrm{M}$; transients per minute in control: $0.45 \pm 0.07$; nimodipine: $0.10 \pm 0.03$ ). Subsequent washout of 
$A_{1}$

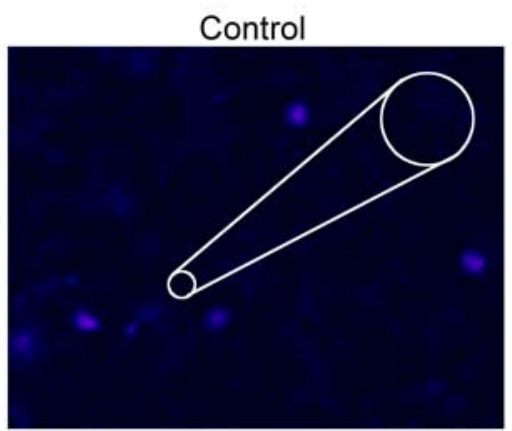

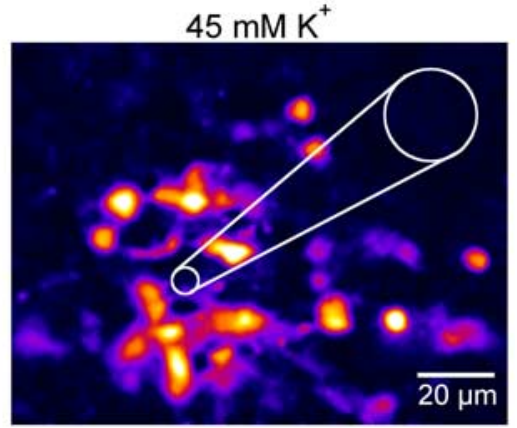

$\mathrm{A}_{2}$

Control

Nimodipine

BayK 8644
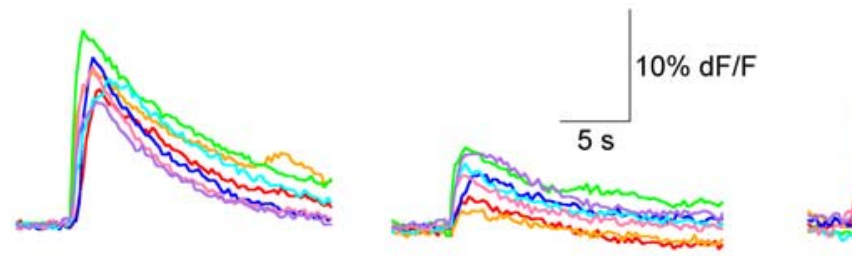

Figure 5. Depolarization-evoked $\mathrm{Ca}^{2+}$ transients in NPCs in the olfactory bulb mediated by L-type $\mathrm{Ca}^{2+}$ channels. $\boldsymbol{A}_{\boldsymbol{1}}$, Delta F/F image of SEL NPCs before and after focal application of $45 \mathrm{~mm} \mathrm{~K}{ }^{+} . \boldsymbol{A}_{\mathbf{2}}$, Evoked responses from several individual NPCs in $\boldsymbol{A}_{\boldsymbol{1}}$ under control conditions, after application of nimodipine, and subsequent washout of nimodipine with BayK 8644.

formed in the presence of $\mathrm{Na}^{+}$channel, $\mathrm{GABA}_{\mathrm{A}} \mathrm{R}, \mathrm{AMPAR}$ and NMDAR blockers. Bath application of nimodipine $(30 \mu \mathrm{M})$ (Fig. $7 A$ ) ( $n=47$ cells, 3 slices) or BayK (5 $\mu \mathrm{M})$ (Fig. $7 B)(n=47$ cells, 4 slices $)$ had no effect on average NPC migration velocity, suggesting that L-type $\mathrm{Ca}^{2+}$ channels do not modulate NPC migration over the time course of our experiments.

To further explore the potential role of $\mathrm{Ca}^{2+}$ influx through L-type $\mathrm{Ca}^{2+}$ channels on NPC migration, we studied whether SEL cell migration was dependent on extracellular $\mathrm{Ca}^{2+}$. We found that slice health and cell morphology were severely degraded with prolonged exposure to $\mathrm{Ca}^{2+}$-free aCSF; SEL cells, which are typically bipolar (Fig. 6), retracted their processes and became round (data not shown) presumably because $\mathrm{Ca}^{2+}$-dependent cell adhesion molecules were disrupted. To overcome this problem, we used aCSF containing $1 \mathrm{~mm}$ EGTA, $0.5 \mathrm{mM} \mathrm{Ca}^{2+}$ and $3.3 \mathrm{mM} \mathrm{Mg}^{2+}$. This concentration of divalent ions and $\mathrm{Ca}^{2+}$ buffer yields a predicted free extracellular $\mathrm{Ca}^{2+}$ concentration of $\sim 60 \mathrm{~nm}$ (Patton et al., 2004). Additionally, slices were loaded with the

nimodipine in the presence of the L-type $\mathrm{Ca}^{2+}$ agonist BayK 8644 restored and enhanced spontaneous activity ( $5 \mu \mathrm{M}$; transients per minute: $1.22 \pm 0.12$ ). These results indicate that L-type $\mathrm{Ca}^{2+}$ channels govern spontaneous $\mathrm{Ca}^{2+}$ transients in NPCs.

$\mathrm{Ca}^{2+}$ transients could also be evoked by direct depolarization via brief focal application of aCSF containing $45 \mathrm{~mm} \mathrm{~K}{ }^{+}$(Fig. $\left.5 A_{1}\right)$ ( $n=3$ slices). Evoked unitary events ( $n=22$ cells) had rise $(850 \pm 60 \mathrm{~ms})$ and decay times $(5.9 \pm 0.4 \mathrm{~s})$ that were indistinguishable from spontaneous $\mathrm{Ca}^{2+}$ transients (Fig. $5 A_{2}$ ). The amplitudes of depolarization-evoked $\mathrm{Ca}^{2+}$ transients were reduced markedly by nimodipine and enhanced by subsequent washout into solution containing BayK 8644 (Fig. 5 $A_{2}$ ). Together, these findings indicate that both spontaneous and depolarizationevoked rises in intracellular $\mathrm{Ca}^{2+}$ are largely mediated by L-type $\mathrm{Ca}^{2+}$ channels.

To observe migration of NPCs, we focally loaded cells in the SEL with the cell-permeable fluorescent dye CellTracker Green CMFDA (CTG) and collected time lapse data using two-photon microscopy. NPC motility was quantified by measuring the distance traveled over time (velocity) of visually distinct cell somata $(\sim 10-20$ cells/experiment) in the $x, y$ plane (Fig. $6 \mathrm{~A}$; supplemental Movie 1, available at www.jneurosci.org as supplemental material). Similar to previous reports of RMS migration (Bolteus and Bordey, 2004; Bolteus et al., 2005; Nam et al., 2007), our data show that cells migrate in both rostral and caudal tangential directions in the olfactory bulb SEL. We also find cells moving radially toward outer cell layers of the olfactory bulb. NPC migration was "saltatory," usually proceeding gradually along small distances with occasional larger translocations of the somata (Fig. $6 B)$. NPCs migrated at an average rate per cell of $49.5 \pm 2.8 \mu \mathrm{m} / \mathrm{h}$ with an average peak velocity per cell of $112.4 \pm 3.7 \mu \mathrm{m} / \mathrm{h}(n=$ 420 cells, 24 slices).

Given that NPCs express L-type $\mathrm{Ca}^{2+}$ channels that provide a route for $\mathrm{Ca}^{2+}$ influx, we examined whether modulation of these channels regulates NPC migration. All experiments were per- cell-permeable $\mathrm{Ca}^{2+}$ chelator EGTA-AM $(50 \mu \mathrm{M})$ to further limit increases in intracellular $\mathrm{Ca}^{2+}$. Application of this nominally $\mathrm{Ca}^{2+}$-free aCSF had no acute effect on average NPC migration velocity (Fig. $7 C$ ). We also compared average migration velocity for cells in slices maintained under control conditions or superfused with nominally $\mathrm{Ca}^{2+}$-free aCSF and EGTA-AM for at least $90 \mathrm{~min}$. Even after prolonged incubation in nominally $\mathrm{Ca}^{2+}$-free aCSF, SEL cell migration was indistinguishable from control conditions (control: $55.3 \pm 2.8 \mu \mathrm{m} / \mathrm{h}, n=63$ cells, 5 slices; nominally $\mathrm{Ca}^{2+}$-free aCSF: $59.8 \pm 3.0 \mu \mathrm{m} / \mathrm{h}, n=105$ cells, 6 slices). However, disrupting actin polymerization with bath application of cytochalasin D (2.5 $\mu \mathrm{M})$ (Fig. $7 D)(n=50$ cells, 2 slices) rapidly reduced NPC migration confirming that motility is actindependent and that we could detect alterations in migration rate. Thus, despite the important role of signaling through voltagegated $\mathrm{Ca}^{2+}$ channels for migration in other cell types, our results indicate that $\mathrm{Ca}^{2+}$ influx via these channels in olfactory bulb NPCs does not influence migration.

\section{Discussion}

In this study, we have examined $\mathrm{Ca}^{2+}$ signaling in NPCs of the postnatal olfactory bulb and tested whether manipulation of intracellular $\mathrm{Ca}^{2+}$ in these cells regulates migration. We show that, in addition to $\mathrm{K}^{+}$and $\mathrm{Na}^{+}$channels, NPCs in olfactory bulb slices express L-type $\mathrm{Ca}^{2+}$ channels that govern spontaneous elevations in intracellular $\mathrm{Ca}^{2+}$. Although dihydropyridine agonists and antagonists modulate the frequency of SEL $\mathrm{Ca}^{2+}$ transients, manipulation of L-type $\mathrm{Ca}^{2+}$ channel activity does not influence NPC migration.

Previous electrophysiological studies of the membrane properties of cells in the postnatal SVZ and RMS found that NPCs express small voltage-gated $\mathrm{Na}^{+}$currents and larger $\mathrm{K}^{+}$currents mediated by TEA-sensitive $\mathrm{K}^{+}$channels (Belluzzi et al., 2003; Wang et al., 2003b). In these brain regions, NPCs had an estimated resting membrane potential of $-60 \mathrm{mV}$ and depolarizing 
current injection failed to generate fast action potentials. Our results indicate that olfactory bulb SEL cells continue to express small $\mathrm{Na}^{+}$currents relative to $\mathrm{K}^{+}$ currents and are unable to generate fast action potentials. These findings are consistent with the notion that NPCs are "nonexcitable," immature neurons. However, in the presence of TEA, we found that depolarization gave rise to slow, regenerative $\mathrm{Ca}^{2+}$ spikes in SEL NPCs. Indeed, voltage-clamp recordings in which $\mathrm{Na}^{+}$ and $\mathrm{K}^{+}$channels were blocked revealed high-voltage-activated L-type $\mathrm{Ca}^{2+}$ currents in SEL cells. These results indicate that SEL NPCs possess L-type $\mathrm{Ca}^{2+}$ channels that could influence levels of intracellular $\mathrm{Ca}^{2+}$.

Although SEL NPCs lack fast action potentials, our imaging experiments revealed that NPCs generate spontaneous $\mathrm{Ca}^{2+}$ transients. Although we observed spontaneous transients in $25-50 \%$ of SEL cells, this is likely an underestimate given their sporadic nature and tendency to occur in bursts. Our observations are consistent with a preliminary report of spontaneous $\mathrm{Ca}^{2+}$ transients observed in 50\% of RMS cells (Platel et al., 2008a). However, the mechanisms governing $\mathrm{Ca}^{2+}$ transients in RMS cells have not been previously investigated. Our experiments reveal that transients in SEL cells were unaffected by TTX and blockers of ionotropic glutamate and GABA receptors, suggesting that they are an intrinsic property of NPCs. Indeed, directly increasing membrane excitability with high $\mathrm{K}^{+}$increased the frequency of NPC Ca ${ }^{2+}$ transients suggesting a role for voltage-gated $\mathrm{Ca}^{2+}$ channels. Both spontaneous and depolarization-evoked $\mathrm{Ca}^{2+}$ transients were blocked by the L-type $\mathrm{Ca}^{2+}$ channel blocker nimodipine and enhanced by the dihydropyridine agonist BayK 8644 . These pharmacological experiments indicate that $\mathrm{Ca}^{2+}$ influx via L-type channels underlies $\mathrm{Ca}^{2+}$ transients in SEL NPCs.

What leads to the opening of high-voltage-activated L-type channels mediating spontaneous $\mathrm{Ca}^{2+}$ transients in SEL NPCs? Given the high input resistance (3-4 G $\Omega$ ) of NPCs, small changes in membrane current would cause marked changes in cell membrane potential. For example, the stochastic closure of just a few $\mathrm{K}^{+}$channels open at the resting membrane potential would lead to a large enough depolarization of SEL cells to activate L-type $\mathrm{Ca}^{2+}$ channels.

Ionotropic receptors have been suggested to influence the migration rate of neuroblasts in slices containing the SVZ and RMS. Kainate receptor agonists activate currents and increase intracellular $\mathrm{Ca}^{2+}$ in migrating neuroblasts (Platel et al., 2008b). Application of kainate receptor antagonists enhanced the rate of neuroblast migration in the SVZ, suggesting that tonic activation of kainate receptors decreases the speed of neuroblast migration (Platel et al., 2008b). In addition, activation of $\mathrm{GABA}_{\mathrm{A}} \mathrm{Rs}$ has
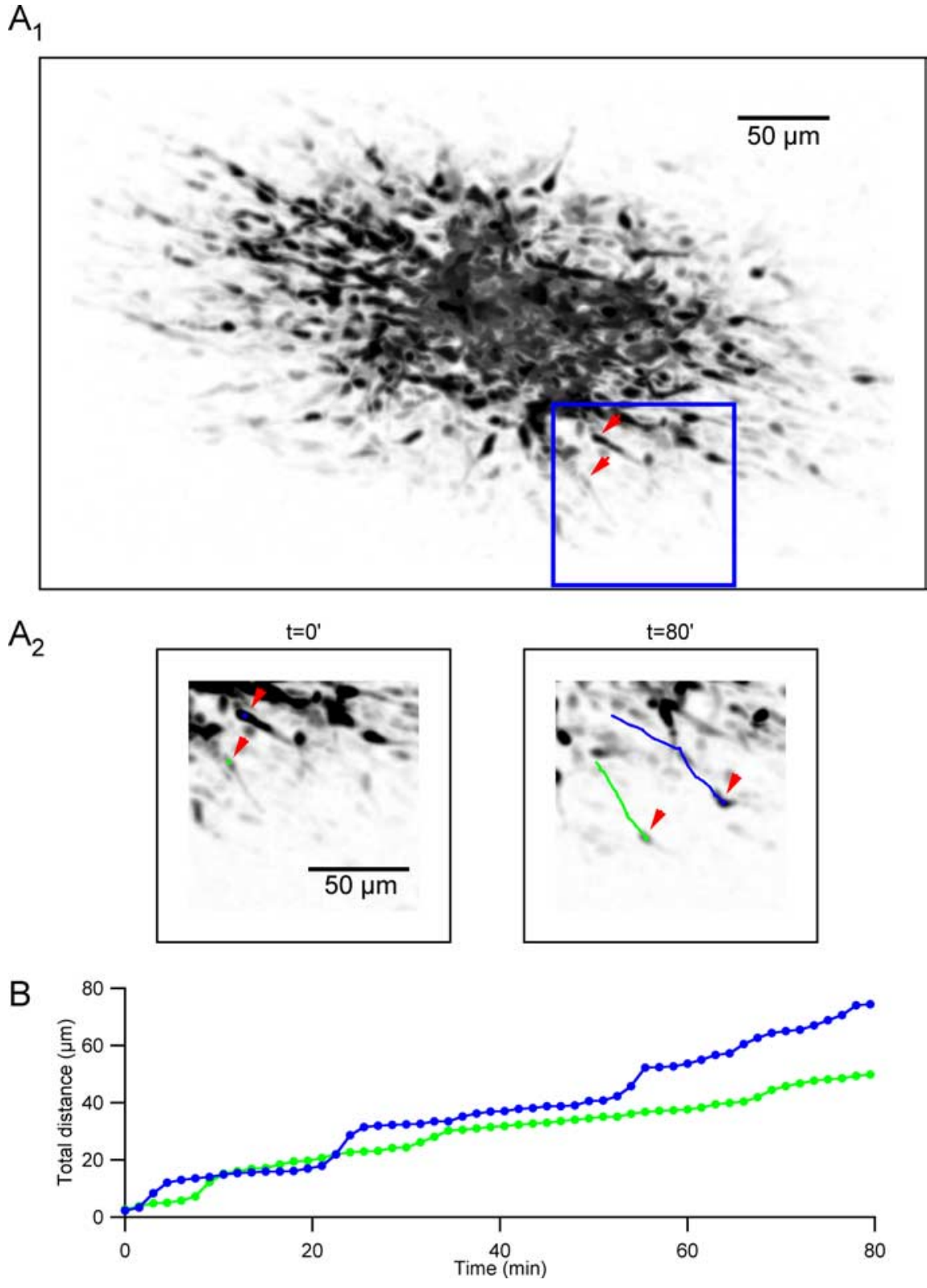

Figure 6. Quantifying NPC migration in olfactory bulb slices. $\boldsymbol{A}_{1}$, Example migration experiment showing NPCs focally labeled with CellTracker Green CMFDA. $\boldsymbol{A}_{2}$, Inset showing migration path or celltracks for 2 NPCs (red arrows). $\boldsymbol{B}$, Total distance plotted for the 2 NPCs in $\boldsymbol{A}_{\mathbf{2}}$ demonstrating gradual movement interspersed with larger translocations of the soma.

been shown to depolarize olfactory neuroblasts in the SVZ and RMS (Wang et al., 2003a), generate an increase in neuroblast intracellular $\mathrm{Ca}^{2+}$ (Platel et al., 2008b), and reduce their rate of migration (Bolteus and Bordey, 2004). One possible explanation for these findings is that both tonic and evoked $\mathrm{Ca}^{2+}$ influx lead to a reduction in migration rate of olfactory neuroblasts. However, other observations are difficult to reconcile with a simple model in which increases in intracellular $\mathrm{Ca}^{2+}$ are coupled to a reduction in migration. For example, loading slices with the calcium chelator BAPTA-AM or adding EGTA to the extracellular medium was found to reduce the migration rate of cells in the SVZ and RMS, suggesting that $\mathrm{Ca}^{2+}$ influx enhances migration (Bolteus and Bordey, 2004). Furthermore, activation of metabotropic glutamate receptors causes a rise in intracellular $\mathrm{Ca}^{2+}$ in SVZ neuroblasts but does not alter their migration (Platel et al., 2008b) and $\mathrm{GABA}_{\mathrm{A}}$ Rs were suggested to alter migration indepen- 
$\mathrm{A}_{1}$ Control Nimodipine

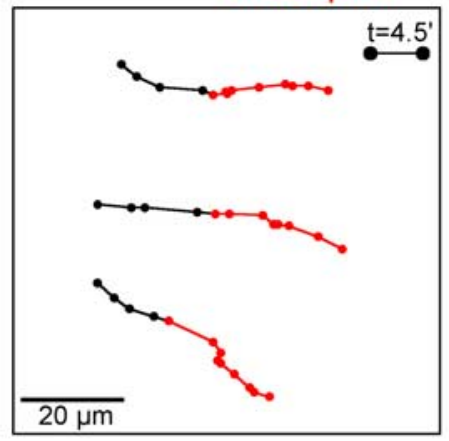

$\mathrm{A}_{2}$

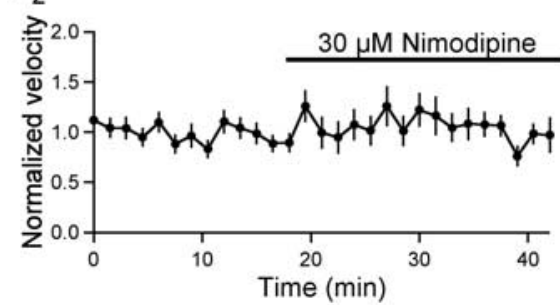

$\mathrm{C}_{1}$

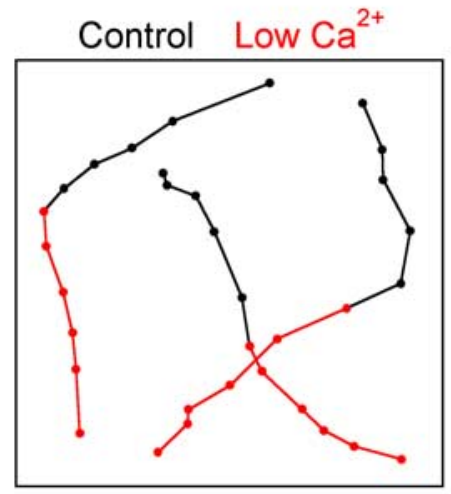

$\mathrm{C}_{2}$

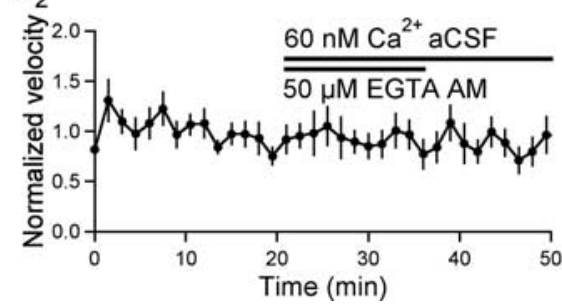

$\mathrm{B}_{1}$

Control BayK 8644

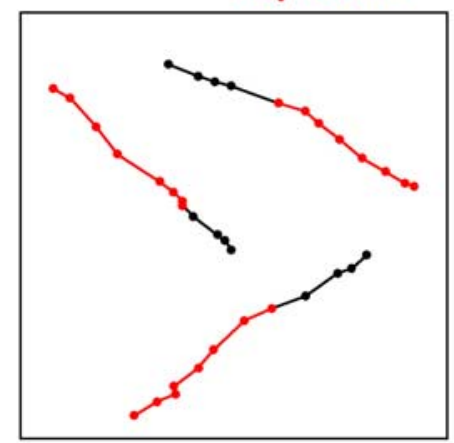

$\mathrm{B}_{2}$

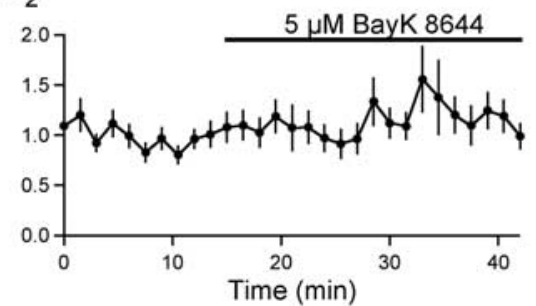

$D_{1}$ Control Cytochalasin D

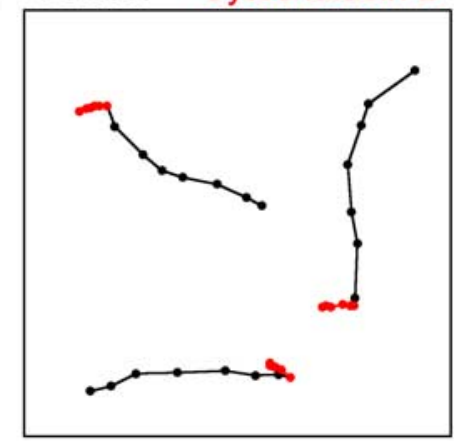

$\mathrm{D}_{2}$

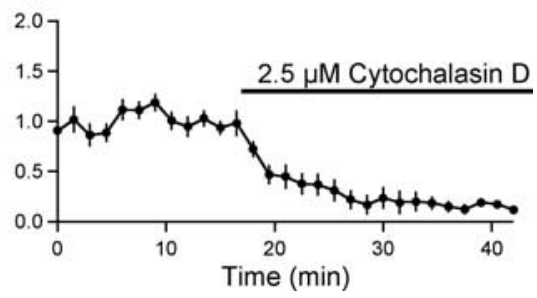

Figure 7. Effects of $\mathrm{Ca}^{2+}$-channel manipulation on migration of NPCs. $A_{1}$, Example celltracks of NPCs migrating under control conditions (black) and in the presence of nimodipine (red). $A_{2}$, Average time course of migration with bath application of nimodipine ( $n=47$ cells, 3 slices). $\boldsymbol{B}_{1}$, Example celltracks of migration under control conditions (black) and during exposure to BayK 8644 (red). $\boldsymbol{B}_{2}$, Average time course of migration with application of BayK 8644 ( $n=47$ cells, 4 slices). $\boldsymbol{C}_{1}$, Example celltracks of migration under control conditions (black) and after wash-in of aCSF containing $60 \mathrm{~nm} \mathrm{Ca}^{2+}$ and $50 \mu \mathrm{M}$ EGTA-AM (red). $C_{2}$, Average time course of migration during application of nominally $\mathrm{Ca}^{2+}$-free aCSF and EGTA-AM ( $n=23$ cells, 1 slice). $\boldsymbol{D}_{1}$, Example celltracks of migration under control conditions (black) and during exposure to cytochalasin $D$ (red). $\boldsymbol{D}_{2}$, Average time course of migration with application of cytochalasin D ( $n=50$ cells, 2 slices).

dently of membrane depolarization or $\mathrm{Ca}^{2+}$ influx by interfering with intracellular $\mathrm{Ca}^{2+}$ stores through an unknown pathway (Bolteus and Bordey, 2004). A greater knowledge of the routes governing $\mathrm{Ca}^{2+}$ influx and intracellular $\mathrm{Ca}^{2+}$ signaling could yield a better understanding of the interplay between $\mathrm{Ca}^{2+}$ and migration in olfactory NPCs.

We considered the possibility that $\mathrm{Ca}^{2+}$ influx via L-type channels might modulate SEL NPC migration. However, despite their dramatic actions on $\mathrm{Ca}^{2+}$ transients, neither nimodipine, nor BayK 8644 had significant effects on the migration rate of SEL NPCs. In agreement with these results, we find that SEL migration is unaltered when slices are loaded with EGTA-AM and superfused with nominally $\mathrm{Ca}^{2+}$-free aCSF, conditions that greatly reduce $\mathrm{Ca}^{2+}$ influx and elevations in intracellular $\mathrm{Ca}^{2+}$. Together, our findings suggest that $\mathrm{Ca}^{2+}$ transients due to voltage-gated $\mathrm{Ca}^{2+}$ channels do not directly govern SEL cell migration rate. Our results differ from a previous study that found that bath application of $\mathrm{Ca}^{2+}$ chelators reduced the velocity of cells migrating in the SVZ and RMS of acute slices (Bolteus and Bordey, 2004). However, experimental variations in cell types studied (SVZ/anterior RMS vs SEL cells), technique (video DIC imaging of surface cells vs two-photon imaging of deeper cells), or extracellular solution (culture medium vs aCSF containing ionotropic channel blockers) could account for these differences.

Together, our findings suggest that modulation of $\mathrm{Ca}^{2+}$ influx through voltage-gated $\mathrm{Ca}^{2+}$ channels is not a mechanism for the regulation of migration of olfactory bulb NPCs. This is in contrast to granule cells of the developing cerebellum, in which $\mathrm{Ca}^{2+}$ influx via $\mathrm{N}$-type $\mathrm{Ca}^{2+}$ channels (Komuro and Rakic, 1992) tightly regulates cell migration. Our results suggest that the role of $\mathrm{Ca}^{2+}$ differs between neural precursors in the olfactory bulb and cells that migrate during early postnatal development in other brain regions. Rather than acutely regulating migration in olfactory bulb NPCs, intracellular $\mathrm{Ca}^{2+}$ may govern long-term cellular events, such as differentiation and maturation, via transcriptional regulation.

\section{References}

Alonso M, Viollet C, Gabellec MM, Meas-Yedid V, Olivo-Marin JC, Lledo PM (2006) Olfactory discrimination learning increases the survival of adult-born neurons in the olfactory bulb. J Neurosci 26:10508-10513.

Baker H, Liu N, Chun HS, Saino S, Berlin R, Volpe B, Son JH (2001) Phenotypic differentiation during migration of dopaminergic progenitor cells to the olfactory bulb. J Neurosci 21:8505-8513.

Belluzzi O, Benedusi M, Ackman J, LoTurco JJ (2003) Electrophysiological differentiation of new neurons in the olfactory bulb. J Neurosci 23:10411-10418.

Bolteus AJ, Bordey A (2004) GABA release and uptake regulate neuronal precursor migration in the postnatal subventricular zone. J Neurosci 24:7623-7631.

Bolteus AJ, Garganta C, Bordey A (2005) Assays for measuring extracellular GABA levels and cell migration rate in acute slices. Brain Res Brain Res Protoc 14:126-134. 
Brown J, Cooper-Kuhn CM, Kempermann G, Van Praag H, Winkler J, Gage FH, Kuhn HG (2003a) Enriched environment and physical activity stimulate hippocampal but not olfactory bulb neurogenesis. Eur J Neurosci 17:2042-2046.

Brown JP, Couillard-Després S, Cooper-Kuhn CM, Winkler J, Aigner L, Kuhn HG (2003b) Transient expression of doublecortin during adult neurogenesis. J Comp Neurol 467:1-10.

Carleton A, Petreanu LT, Lansford R, Alvarez-Buylla A, Lledo PM (2003) Becoming a new neuron in the adult olfactory bulb. Nat Neurosci 6:507-518.

Curtis MA, Kam M, Nannmark U, Anderson MF, Axell MZ, Wikkelso C, Holtås S, van Roon-Mom WM, Björk-Eriksson T, Nordborg C, Frisén J, Dragunow M, Faull RL, Eriksson PS (2007) Human neuroblasts migrate to the olfactory bulb via a lateral ventricular extension. Science 315:1243-1249.

Eriksson PS, Perfilieva E, Björk-Eriksson T, Alborn AM, Nordborg C, Peterson DA, Gage FH (1998) Neurogenesis in the adult human hippocampus. Nat Med 4:1313-1317.

Gage FH (2002) Neurogenesis in the adult brain. J Neurosci 22:612-613.

Gleeson JG, Lin PT, Flanagan LA, Walsh CA (1999) Doublecortin is a microtubule-associated protein and is expressed widely by migrating neurons. Neuron 23:257-271.

Gomez TM, Spitzer NC (1999) In vivo regulation of axon extension and pathfinding by growth-cone calcium transients. Nature 397:350-355.

Gomez TM, Robles E, Poo M, Spitzer NC (2001) Filopodial calcium transients promote substrate-dependent growth cone turning. Science 291:1983-1987.

Gross CG (2000) Neurogenesis in the adult brain: death of a dogma. Nat Rev Neurosci 1:67-73.

Kempermann G, Kuhn HG, Gage FH (1997) More hippocampal neurons in adult mice living in an enriched environment. Nature 386:493-495.

Komuro H, Rakic P (1992) Selective role of N-type calcium channels in neuronal migration. Science 257:806-809.

Komuro H, Rakic P (1996) Intracellular Ca2+ fluctuations modulate the rate of neuronal migration. Neuron 17:275-285.

Komuro H, Rakic P (1998) Orchestration of neuronal migration by activity of ion channels, neurotransmitter receptors, and intracellular $\mathrm{Ca} 2+$ fluctuations. J Neurobiol 37:110-130.

Lautermilch NJ, Spitzer NC (2000) Regulation of calcineurin by growth cone calcium waves controls neurite extension. J Neurosci 20:315-325.

Lois C, Alvarez-Buylla A (1994) Long-distance neuronal migration in the adult mammalian brain. Science 264:1145-1148.

Luskin MB (1998) Neuroblasts of the postnatal mammalian forebrain: their phenotype and fate. J Neurobiol 36:221-233.
Magavi SS, Mitchell BD, Szentirmai O, Carter BS, Macklis JD (2005) Adultborn and preexisting olfactory granule neurons undergo distinct experience-dependent modifications of their olfactory responses in vivo. J Neurosci 25:10729-10739.

Ming GL, Song H (2005) Adult neurogenesis in the mammalian central nervous system. Annu Rev Neurosci 28:223-250.

Nacher J, Crespo C, McEwen BS (2001) Doublecortin expression in the adult rat telencephalon. Eur J Neurosci 14:629-644.

Nam SC, Kim Y, Dryanovski D, Walker A, Goings G, Woolfrey K, Kang SS, Chu C, Chenn A, Erdelyi F, Szabo G, Hockberger P, Szele FG (2007) Dynamic features of postnatal subventricular zone cell motility: a twophoton time-lapse study. J Comp Neurol 505:190-208.

Owens DF, Kriegstein AR (1998) Patterns of intracellular calcium fluctuation in precursor cells of the neocortical ventricular zone. J Neurosci 18:5374-5388.

Patton C, Thompson S, Epel D (2004) Some precautions in using chelators to buffer metals in biological solutions. Cell Calcium 35:427-431.

Petreanu L, Alvarez-Buylla A (2002) Maturation and death of adult-born olfactory bulb granule neurons: role of olfaction. J Neurosci 22:6106-6113.

Platel JC, Dave KA, Bordey A (2008a) Control of neuroblast production and migration by converging GABA and glutamate signals in the postnatal forebrain. J Physiol 586:3739-3743.

Platel JC, Heintz T, Young S, Gordon V, Bordey A (2008b) Tonic activation of GLUK5 kainate receptors decreases neuroblast migration in wholemounts of the subventricular zone. J Physiol 586:3783-3793.

van Praag H, Schinder AF, Christie BR, Toni N, Palmer TD, Gage FH (2002) Functional neurogenesis in the adult hippocampus. Nature 415:1030-1034.

van Praag H, Shubert T, Zhao C, Gage FH (2005) Exercise enhances learning and hippocampal neurogenesis in aged mice. J Neurosci 25:8680-8685.

Wang DD, Krueger DD, Bordey A (2003a) GABA depolarizes neuronal progenitors of the postnatal subventricular zone via GABAA receptor activation. J Physiol 550:785-800.

Wang DD, Krueger DD, Bordey A (2003b) Biophysical properties and ionic signature of neuronal progenitors of the postnatal subventricular zone in situ. J Neurophysiol 90:2291-2302.

Wen Z, Guirland C, Ming GL, Zheng JQ (2004) A CaMKII/calcineurin switch controls the direction of $\mathrm{Ca}(2+)$-dependent growth cone guidance. Neuron 43:835-846.

Zheng JQ (2000) Turning of nerve growth cones induced by localized increases in intracellular calcium ions. Nature 403:89-93. 